\section{$\mathrm{NIH}$ gives the go-ahead on genetic experiment}

The controversial first experiment to involve the insertion of foreign genes into humans - which has been deliberated by seven US review committees and government agencies over the past several months - received approval to proceed last week. James Wyngaarden, director of the US National Institutes of Health (NIH), authorized Steven A. Rosenberg and W. French Anderson to readminister interleukin-2-stimulated T-lymphocytes marked with a gene for neomycin resistance to ten cancer patients from whom the cells were isolated. The inserted gene will provide no therapeutic benefit to the patients, but will enable Rosenberg and Anderson to determine if the cells return to the tumour to fight the cancer.

C.E.

\section{Vet schools to close}

THE University Grants Committee announ ced last week that two of Britain's six veterinary schools are to close. A working party appointed to consider the rationalization of veterinary education said that no school is at present able to teach clinical science with the necessary spread of disciplines and depth of coverage.

The schools at the Universities of Glasgow and Edinburgh will be merged to form a new school based in Edinburgh, and veterinary deg-rees will no longer be obtainable at the University of Cambridge. The last intake of students will be for the academic year 1989-90. The remaining schools, at the Universities of Bristol, Liverpool, London and Edinburgh, will have no fewer than 36 senior clinical teachers and will teach about 76 students each year.

C. McG.

\section{Scientists for Phobos}

Ten US scientists, including Bruce Murray of the California Institute of Technology and Thomas Duxbury of the Jet Propulsion Laboratory, have been selected to participate in the Soviet Phobos mission, due to reach Mars and its satellite by April this year. The ten were chosen jointly by the National Aeronautics and Space Administration (NASA) and Soviet delegations to a US - Soviet working group - the working group was set up under the 1987 cooperative agreement on space research between the two countries.

Meanwhile a new agreement to foster scientific cooperation was signed in Paris earlier this month by outgoing US Secretary of State George Schultz and Soviet Foreign Minister Eduard Shevardnadze. In eight general areas, including science policy and problems of the Arctic as well as all the traditional disciplines, US agencies and their Soviet counterparts will draw up plans to facilitate cooperative research.

\title{
More criticism for NIH over 'summary' cut of grants
}

\section{Boston}

THE US National Institutes of Health (NIH) are drawing more fire for their decision to end financial support for two scientists accused of misconduct before an investigation into their case had been completed.

$\mathrm{NIH}$ procedures for investigating misconduct have recently come under heavy criticism. The current case involves two scientists at the Harvard-affiliated Massachusetts Eye and Ear Infirmary. Kenneth Kenyon and Scheffer Tseng (Tseng is now a researcher at the University of Miami) are alleged to have had business interests in an ophthalmic ointment they were testing with funds from $\mathrm{NIH}$ and to have delayed publication of results showing the ointment to be ineffective (see Nature 336, 506; 8 December 1988). NIH suspended their research grants late last year, but are still investigating the affair.

But Claes Dohlman, outgoing chair of the ophthalmology department, this week sent a letter to NIH officials expressing his concern over the agency's action and protesting at what he calls the "summary way" in which NIH reached their decision. Dohlman's letter follows a similar one earlier this month from Charles Schepens and Richard Pharo, respectively president and director of research administration at the Eye Research Institute in Boston.

"To take action in the absence of evidence is unjustifiable", write Schepens and Pharo, adding that NIH's move sends a message to the medical research community that "the federal government is prepared to abandon a scientist without due process". Last month, Representative John Dingell (Democrat, Michigan), chairman of the House of Representatives Energy and Commerce Committee oversight and investigations subcommittee, which has been holding hearings on how scientific misconduct charges are investigated, wrote to Otis Bowen, the Health and Human Services Secretary, with similar complaints about the way the case was handled (see Nature 336, 706; 22 December 1988). Dingell, in a sharply worded letter, accused NIH of reaching their decision solely on the basis of newspaper reports and called upon NIH officials to explain the rationale and precedent for their decision.

In a letter responding to Dingell's concerns, Robert Windom, Assistant Secretary for Health of the Department of Health and Human Services, writes that NIH "acted responsibly" on the basis of the information they had at the time, which he states was "sufficient to demonstrate a clear, urgent need for interim administrative action". Windom claims that, in addition to newspaper accounts, the agency based its decision to terminate Kenyon's and Tseng's financial support upon conversations with Harvard officials and upon a statement written to the Harvard faculty about the case by Daniel $C$. Tosteson, dean of Harvard Medical School. Jack McLaughlin, associate director of the National Eye Institute of NIH, did acknowledge, however, that the agency first learned about the case through newspaper accounts.

Both Windom and McLaughlin assert that there are precedents for NIH's move, although neither points to any specific case. McLaughlin stresses the importance of treating such incidents on "a case-bycase basis", and says only that he is sure that similar "interim actions" have been taken in other cases at NIH.

A staff member on Dingell's subcommittee has called NIH's response "disingenuous" and "inconsistent" with the subcommittee's records of what transpired in NIH's decision. Hearings on the matter by Dingell's subcommittee are expected to begin in early March, and reports are due before that from at least one of NIH's investigations. Seth Shulman

\section{Vice-chancellors' pay offer to staff rejected}

\section{London}

UK university management last week tried temporarily to resolve the pay dispute with staff by offering to increase salaries by 3 per cent from April 1989 and make a lump sum payment at that time equal to a 3 per cent rise for the period from 1 January to 31 March 1989.

After making the offer, the Committee of Vice-Chancellors and Principals acknowledged that it was too low. Sir Mark Richmond, chairman of the committee, said it was embarrassed at the inadequacy of the offer. There was a desperate need to pay academic staff decent salaries, but the committee thought staff would rather be assured of something now while it continued to argue for more. The vice-chancellors are to approach the government for extra money for 1989-90 which would be used by individual universities to reward merit and make discretionary payments to teachers in subjects short of staff.

The Association of University Teachers rejected the offer and will continue its boycott of university examinations. But it was cheered by the vice-chancellors' offer to backdate the offer to cover part of 1988-89.
Christine McGourty 